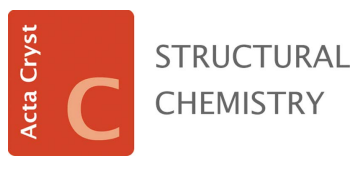

ISSN 2053-2296

Received 21 July 2020

Accepted 25 August 2020

Edited by A. Lemmerer, University of the Witwatersrand, South Africa

Keywords: molybdenum(V) oxohalide; crystal structure; Hirshfeld surface analysis.

CCDC reference: 2013034

Supporting information: this article has supporting information at journals.iucr.org/c

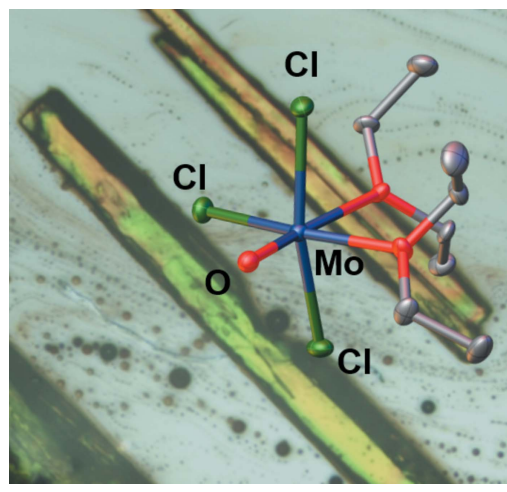

C 2020 International Union of Crystallography

\section{Crystal structure and Hirshfeld surface analysis of the elusive trichlorobis(diethyl ether)oxo- molybdenum(V)}

\author{
Thomas E. Shaw, ${ }^{\mathrm{a}, \mathrm{b}}$ Pierre LeMagueres, ${ }^{\mathrm{c}}$ Alfred P. Sattelberger ${ }^{\mathrm{a} *}$ and Titel Jurca $\mathrm{a}^{\mathrm{a}, \mathrm{b} *}$
}

${ }^{\mathbf{a}}$ Department of Chemistry, University of Central Florida, Orlando, FL 32816, USA, ${ }^{\mathbf{b}}$ Renewable Energy and Chemical Transformations Cluster, University of Central Florida, Orlando, FL 32816, USA, and ${ }^{\mathrm{C}}$ Rigaku Americas Corporation, The Woodlands, TX 77381, USA. *Correspondence e-mail: al.sattelberger@knights.ucf.edu, titel.jurca@ucf.edu

First reported in $1930, \mathrm{MoCl}_{3} \mathrm{O}\left(\mathrm{Et}_{2} \mathrm{O}\right)_{2}$ is a by-product of the reductive synthesis of $\mathrm{MoCl}_{4}\left(\mathrm{OEt}_{2}\right)_{2}$ from $\mathrm{MoCl}_{5}$. We report herein the X-ray crystal structure and Hirshfeld surface characteristics of mer $-\mathrm{MoCl}_{3} \mathrm{O}\left(\mathrm{Et}_{2} \mathrm{O}\right)_{2}$, or $\left[\mathrm{MoCl}_{3} \mathrm{O}\left(\mathrm{C}_{4} \mathrm{H}_{10} \mathrm{O}\right)_{2}\right]$. The compound crystallizes in the orthorhombic space group $P 2_{1} 2_{1} 2_{1}$. The molybdenyl $(\mathrm{Mo}=\mathrm{O})$ bond length is 1.694 (3) $\AA$ and the cis- and trans-Mo-O distances are 2.157 (3) and 2.304 (3) $\AA$, respectively. Intermolecular $\mathrm{Mo}=\mathrm{O} \cdots \mathrm{H}$ bonding is present in the lattice, with the shortest distance being $2.572 \AA$.

\section{Introduction}

The red-orange diethyl ether adduct of molybdenum(IV) chloride, $\mathrm{MoCl}_{4}\left(\mathrm{OEt}_{2}\right)_{2}(\mathbf{1})$, is a useful synthon for mid-valent molybdenum chemistry (Kuiper et al., 2008a,b). It can be prepared anaerobically by reducing a suspension of molybdenum pentachloride, $\mathrm{MoCl}_{5}$, in diethyl ether with any one of the following reductants: norbornene (Castellani \& Gallazzi, 1985), allyltrimethylsilane (Persson \& Andersson, 1993), or elemental tin (Stoffelbach et al., 2001). 1 is sparingly soluble in ether and easily isolated by filtration. The crystalline solid slowly loses ether on standing at room temperature and more rapidly under vacuum. Each of the published preparations provide 1 in $\geq 80 \%$ yield. Two of the reported syntheses (Castellani \& Gallazzi, 1985; Stoffelbach et al., 2001) note that if either the diethyl ether is not sufficiently dry and/or the $\mathrm{MoCl}_{5}$ is contaminated with oxyhalides, the green molybdenum $(\mathrm{V})$ oxo-chloro compound $\mathrm{MoCl}_{3} \mathrm{O}\left(\mathrm{OEt}_{2}\right)_{2}(2)$ forms as a by-product. The latter compound was first reported in 1930 (Wardlaw \& Webb, 1930). The solid-state structure of $\mathbf{2}$ (Scheme 1) has never been reported and is the subject of the present work.

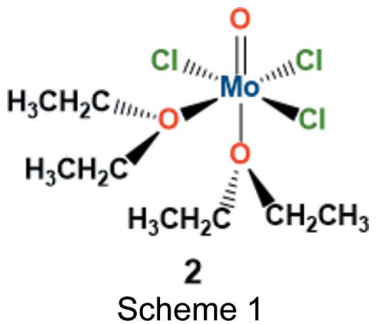

\section{Experimental}

\subsection{Synthesis and crystallization}

Compound 1 was prepared essentially as described by Persson \& Andersson (1993), by adding excess $\mathrm{C}_{3} \mathrm{H}_{5} \mathrm{SiMe}_{3}$ dropwise to a stirred diethyl ether suspension of $\mathrm{MoCl}_{5}$ inside 
Table 1

Experimental details.

\begin{tabular}{|c|c|}
\hline \multicolumn{2}{|l|}{ Crystal data } \\
\hline Chemical formula & {$\left[\mathrm{MoCl}_{3} \mathrm{O}\left(\mathrm{C}_{4} \mathrm{H}_{10} \mathrm{O}\right)_{2}\right]$} \\
\hline$M_{\mathrm{r}}$ & 366.53 \\
\hline Crystal system, space group & Orthorhombic, $P 2_{1} 2_{1} 2_{1}$ \\
\hline Temperature $(\mathrm{K})$ & 100 \\
\hline$a, b, c(\AA)$ & $8.6186(7), 12.250(1), 13.5681(11)$ \\
\hline$V\left(\AA^{3}\right)$ & $1432.5(2)$ \\
\hline$Z$ & 4 \\
\hline Radiation type & Мо $K \alpha$ \\
\hline$\mu\left(\mathrm{mm}^{-1}\right)$ & 1.46 \\
\hline Crystal size (mm) & $0.6 \times 0.21 \times 0.16$ \\
\hline \multicolumn{2}{|l|}{ Data collection } \\
\hline Diffractometer & Rigaku XtaLAB Mini II \\
\hline Absorption correction & $\begin{array}{l}\text { Gaussian (CrysAlis PRO; Rigaku } \\
\text { Oxford Diffraction, 2020) }\end{array}$ \\
\hline$T_{\min }, T_{\max }$ & $0.614,0.831$ \\
\hline $\begin{array}{l}\text { No. of measured, independent and } \\
\text { observed }[I>2 \sigma(I)] \text { reflections }\end{array}$ & 7488, 3179, 2959 \\
\hline$R_{\text {int }}$ & 0.042 \\
\hline$(\sin \theta / \lambda)_{\max }\left(\AA^{-1}\right)$ & 0.649 \\
\hline \multicolumn{2}{|l|}{ Refinement } \\
\hline$R\left[F^{2}>2 \sigma\left(F^{2}\right)\right], w R\left(F^{2}\right), S$ & $0.033,0.069,1.01$ \\
\hline No. of reflections & 3179 \\
\hline No. of parameters & 153 \\
\hline $\mathrm{H}$-atom treatment & $\begin{array}{l}\mathrm{H} \text { atoms treated by a mixture of } \\
\text { independent and constrained } \\
\text { refinement }\end{array}$ \\
\hline$\Delta \rho_{\max }, \Delta \rho_{\min }\left(\mathrm{e} \AA^{-3}\right)$ & $0.53,-0.87$ \\
\hline Absolute structure & $\begin{array}{l}\text { Flack } x \text { determined using } 1123 \\
\text { quotients }\left[\left(I^{+}\right)-\left(I^{-}\right)\right] / \\
{\left[\left(I^{+}\right)+\left(I^{-}\right)\right](\text {Parsons et al., }} \\
2013)\end{array}$ \\
\hline Absolute structure parameter & $0.01(5)$ \\
\hline
\end{tabular}

Computer programs: CrysAlis PRO (Rigaku Oxford Diffraction, 2020), SHELXT2018 (Sheldrick, 2015a), SHELXL2018 (Sheldrick, 2015b) and OLEX2 (Dolomanov et al., 2009).

an mBraun inert atmosphere glove-box (water and $\mathrm{O}_{2}$ levels of $\leq 1 \mathrm{ppm}$ ). For practical reasons, the reaction was carried out at approximately $-30{ }^{\circ} \mathrm{C}$ rather than at the reported $-78^{\circ} \mathrm{C}$. The red-orange solid product, which formed immediately at low temperature upon addition of the silane, was stirred for $2 \mathrm{~h}$ at room temperature and then filtered off and washed with fresh diethyl ether collected on an mBraun solvent purification system. The red-orange filtrate was concentrated to $c a$ $15 \mathrm{ml}$, placed in a scintillation vial, and stored in the $-35^{\circ} \mathrm{C}$ freezer of the glove-box. After several days, a well-formed dark-green crystal of $\mathbf{2}$ was observed at the bottom of the vial. A crystal of 2 with dimensions $0.16 \times 0.21 \times 0.60 \mathrm{~mm}$ was removed from the mother liquor, coated with Paratone oil, removed from the glove-box, quickly secured to a MiteGen micromount, and mounted on the diffractometer under a cryostream $(100 \mathrm{~K})$ to prevent the loss of diethyl ether. Notably, $\mathbf{2}$ rapidly degrades in Paratone under ambient conditions (Fig. S1 in the supporting information).

\subsection{Refinement}

Crystal data, data collection and structure refinement details are summarized in Table $1 . \mathrm{H}$ atoms were attached via the riding model at calculated positions.

\section{Results and discussion}

$\mathrm{MoCl}_{3} \mathrm{O}\left(\mathrm{Et}_{2} \mathrm{O}\right)_{2}$ (2) crystallized in the enantiomorphic space group $P 2_{1} 2_{1} 2_{1}$ with a single molecule in the asymmetric unit. The structure and atom-labeling scheme are shown in Fig. 1(a). A partially occupied unit cell, with hydrogen bonding represented by dashed lines, is shown in Fig. 1(b). Expanded packing diagrams of eight unit cells $(2 \times 2 \times 2)$ are displayed in the supporting information (Fig. S2); beyond the description of hydrogen-bonding interactions provided (vide infra), there are no remarkable features requiring further discussion. The isolated $\mathrm{MoCl}_{3} \mathrm{O}\left(\mathrm{Et}_{2} \mathrm{O}\right)_{2}$ complex exists in a distorted octahedral geometry, with the chloro ligands adopting a meridional configuration. This is consistent with predicted structures and analogous oxomolybdenum complexes with

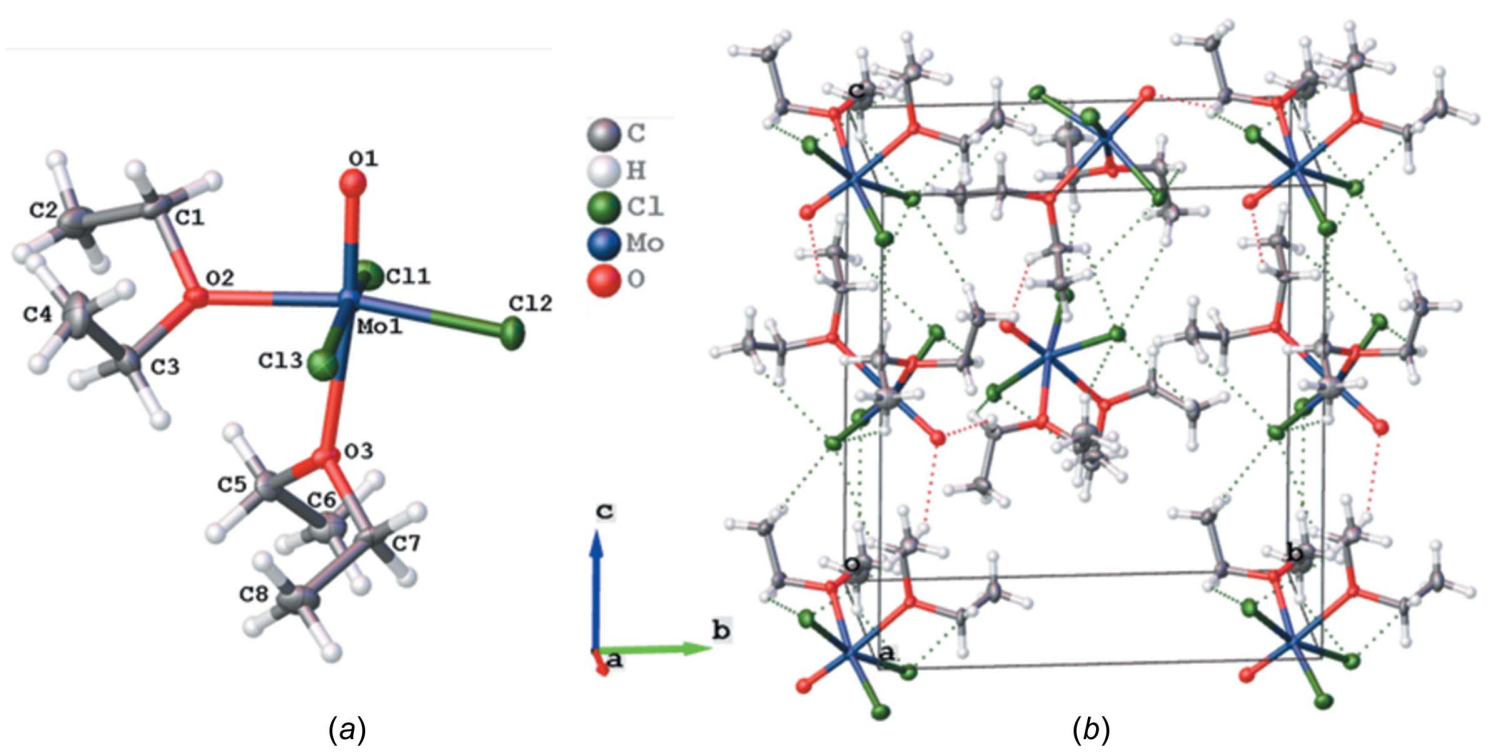

Figure 1

(a)

(b)

(a) The asymmetric unit of 2, showing the labeling scheme for the complex. Displacement ellipsoids are drawn at the $50 \%$ probability level. (b) The partially filled $P 2_{1} 2_{1} 2_{1}$ unit cell of $\mathbf{2}$, showing the inter- and intramolecular hydrogen-bonding interactions. 

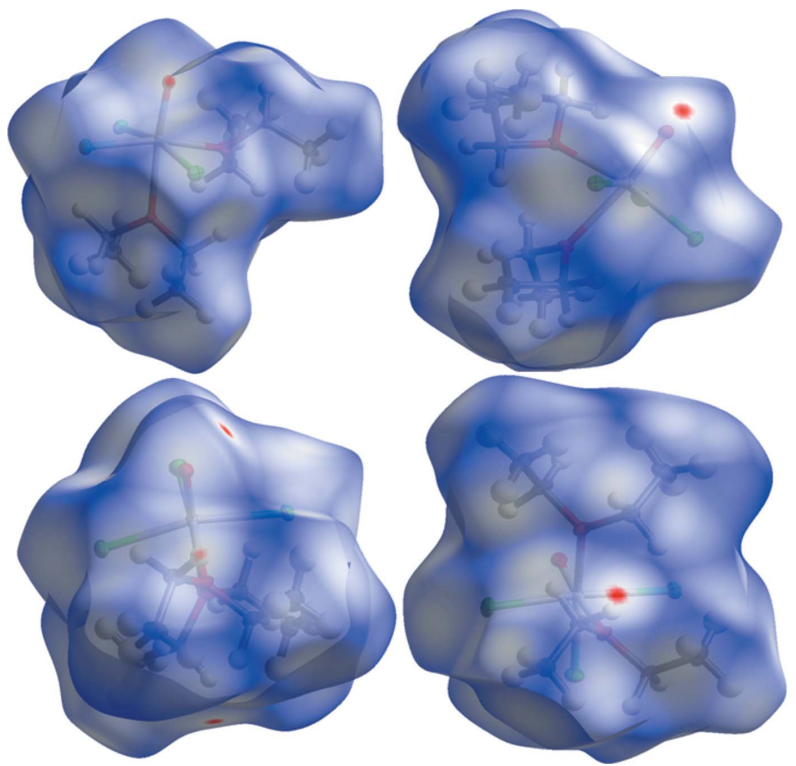

Figure 2

$d_{\text {norm }}$ Hirshfeld surface of $\mathrm{MoCl}_{3} \mathrm{O}\left(\mathrm{Et}_{2} \mathrm{O}\right)_{2}$ from various viewpoints highlighting the areas of intimate contact.

solvent ligands coordinated through the $\mathrm{O}$ heteroatoms (Castellani \& Gallazzi, 1985; Stoffelbach et al., 2001; Vitzthumecker et al., 2017; Marchetti et al., 2013). Selected bond lengths are shown in Table 2, showcasing the metal-to-ligand bond lengths and angles.

As expected, the $\mathrm{O}$ atom of the diethyl ether ligand that is trans to the molybdenum-oxo bond is elongated [2.304 (3) A]
Table 2

Selected geometric parameters $\left(\AA{ }^{\circ}\right)$.

\begin{tabular}{lllc}
\hline Mo1-Cl1 & $2.3469(13)$ & $\mathrm{Mo} 1-\mathrm{O} 3$ & $2.304(3)$ \\
Mo1-Cl3 & $2.3530(13)$ & O2-C1 & $1.468(6)$ \\
Mo1-Cl2 & $2.3159(13)$ & O2-C3 & $1.463(6)$ \\
Mo1-O1 & $1.694(3)$ & O3-C5 & $1.455(5)$ \\
Mo1-O2 & $2.157(3)$ & O3-C7 & $1.463(5)$ \\
& & & \\
O1-Mo1-O3 & $173.06(14)$ & O1-Mo1-O2 & $93.09(14)$ \\
O2-Mo1-Cl2 & $168.30(9)$ & O3-Mo1-Cl2 & $88.37(9)$ \\
Cl1-Mo1-Cl3 & $165.00(5)$ & O3-Mo1-Cl1 & $82.92(8)$ \\
O1-Mo1-Cl2 & $98.48(12)$ & O3-Mo1-Cl3 & $82.19(8)$ \\
O1-Mo1-Cl1 & $98.02(11)$ & O2-Mo1-O3 & $80.10(11)$ \\
O1-Mo1-Cl3 & $96.55(11)$ & &
\end{tabular}

compared to the $\mathrm{O}$ atom trans to a meridional chloro ligand [2.157 (3) §]. In fact, the molybdenum-oxo bond length, as well as the lengths of the meridional chloro ligands, are similar to analogous complexes (Table 3) (Marchetti et al., 2013; Vitzthumecker et al., 2017; Di Nicola et al., 2015). The slight differences in the bond lengths of the meridional chloro ligands can be explained by the donating nature of the coordinating solvents. The only complex with longer $\mathrm{Mo}-$ $\mathrm{O}$ (solvent) bonds is $\mathrm{MoCl}_{3} \mathrm{O}\left(\mathrm{H}_{3} \mathrm{COCH}_{2} \mathrm{CH}_{2} \mathrm{OCH}_{2} \mathrm{Cl}\right)$, which is likely a result of the chloro functioning as a weak electronwithdrawing group. The lability of the diethyl ether ligands and the relatively short lifetime of the isolated $\mathrm{MoCl}_{3} \mathrm{O}$ $\left(\mathrm{Et}_{2} \mathrm{O}\right)_{2}$ complex under ambient conditions can thus be explained by the elongated $\mathrm{Mo}-\mathrm{O}$ (solvent) bonds (Fig. S1 in the supporting information).
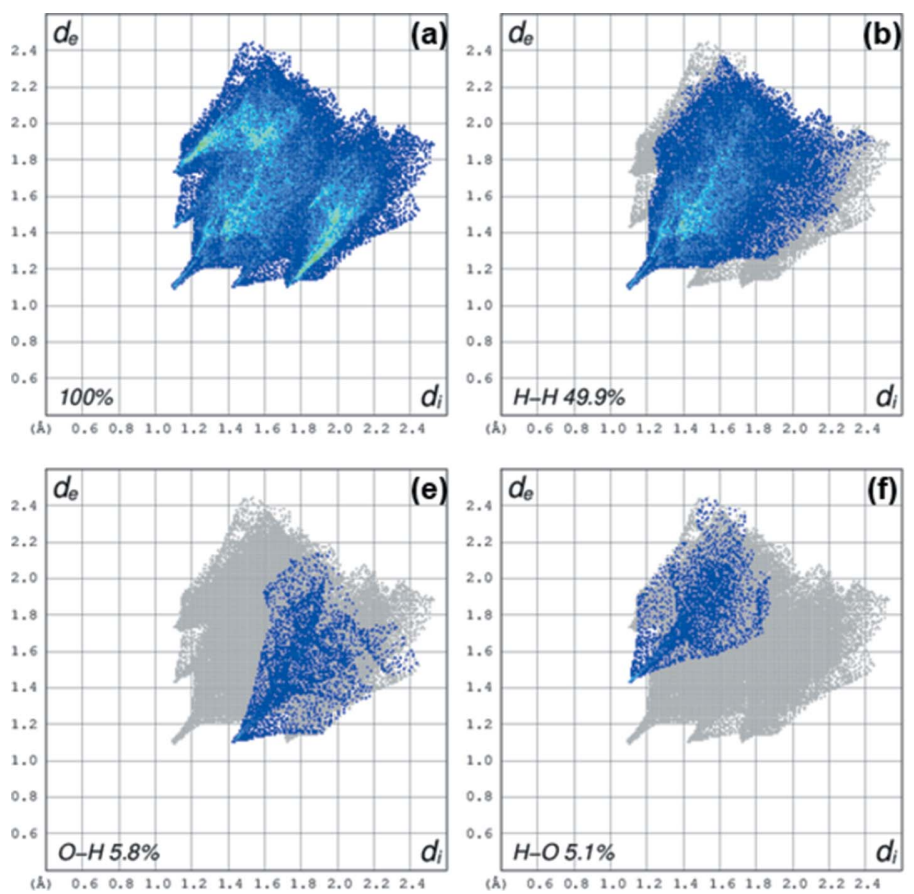
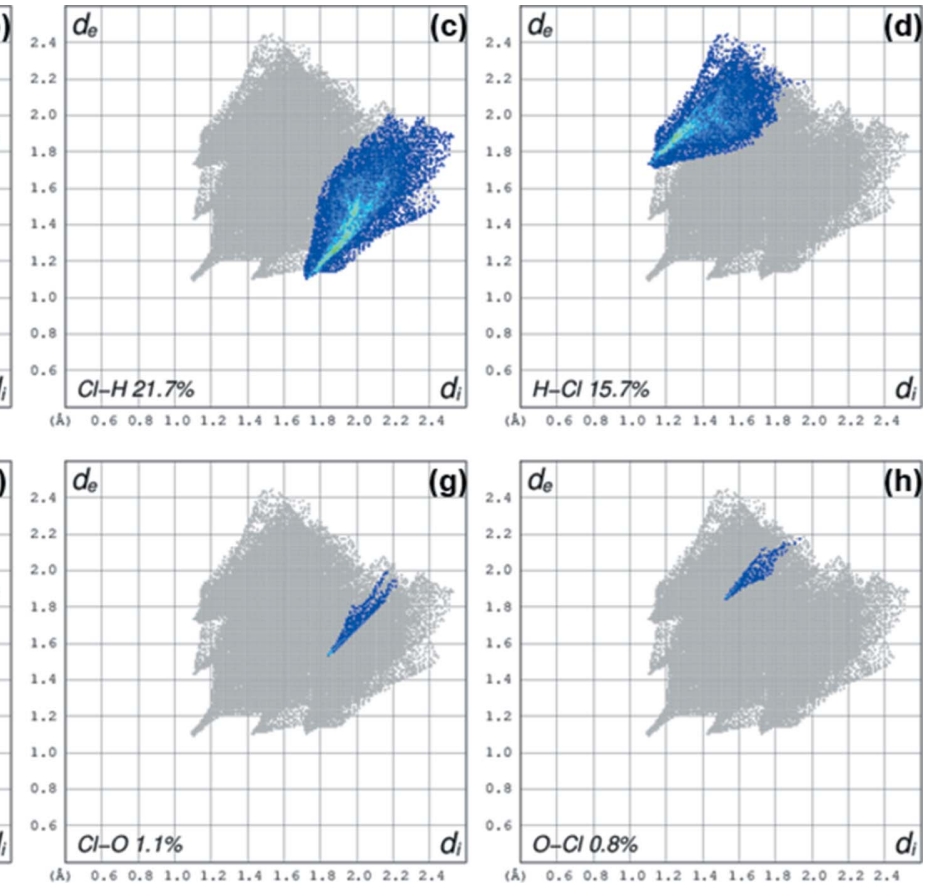

Figure 3

Two-dimensional (2D) fingerprint plots identifying the percent composition of the Hirshfeld surface from the various noncovalent interactions, with the accompanying percent contribution to the Hirshfeld surface: $(a)$ the complete fingerprint plot accounting for all interactions, $(b)$ interactions between interior and exterior $\mathrm{H}$ atoms, $(c)$ interactions between interior $\mathrm{Cl}$ and exterior $\mathrm{H}$ atoms, $(d)$ interactions between interior $\mathrm{H}$ and exterior $\mathrm{Cl}$ atoms, $(e)$ interactions between interior $\mathrm{O}$ and exterior $\mathrm{H}$ atoms, $(f)$ interactions between interior $\mathrm{H}$ and exterior $\mathrm{O}$ atoms, $(g)$ interactions between interior $\mathrm{Cl}$ and exterior $\mathrm{O}$ atoms, and $(h)$ interactions between interior $\mathrm{O}$ and exterior $\mathrm{Cl}$ atoms. 
Table 3

Comparative $\mathrm{Mo}-L$ and $\mathrm{Mo}-X$ bond lengths of $\mathrm{MoCl}_{3} \mathrm{O}\left(\mathrm{Et}_{2} \mathrm{O}\right)_{2}(2)$ and analogous complexes.

The ligand represented by 'thf' is tetrahydrofuran.

\begin{tabular}{|c|c|c|c|}
\hline $\mathrm{MoCl}_{3} \mathrm{O}\left(\mathrm{Et}_{2} \mathrm{O}\right)_{2}$ & $\begin{array}{l}\mathbf{M o C l}_{\mathbf{3}} \mathbf{O}(\mathbf{t h f})_{\mathbf{2}} \\
\text { (Marchetti et al., 2013) }\end{array}$ & $\begin{array}{l}\mathbf{M o C l}_{3} \mathbf{O}(\mathbf{M e O H})_{2} \\
\text { (Vitzthumecker } \text { et al., 2017) }\end{array}$ & $\begin{array}{l}\mathbf{M o C l}_{\mathbf{3}} \mathbf{O}\left[\mathbf{M e O}\left(\mathrm{CH}_{2}\right)_{2} \mathbf{O C H} \mathbf{H}_{\mathbf{2}} \mathbf{C l}\right] \\
\text { (Di Nicola et al., 2015) }\end{array}$ \\
\hline Mo1-Cl1 2.3469 (13) & $\mathrm{Mo}-\mathrm{Cl} 22.3513(9)$ & Mo1-Cl2 2.3642 (8) & Mo1-Cl5 2.3542 (8) \\
\hline Mo1-Cl3 2.3530 (13) & Mo-Cl1 2.3646 (8) & Mo1-Cl1 2.3434 (7) & Mo1-Cl4 2.3453 (7) \\
\hline Mo1-Cl2 2.3159 (13) & Mo-Cl3 2.3191 (9) & Mo1-Cl3 2.3741 (9) & Mo1-Cl2 2.3216 (7) \\
\hline Mo1-O2 2.157 (3) & Mo-O2(thf) 2.146 (2) & Mo-O2 2.099 (2) & Mo1-O2 2.161 (2) \\
\hline Mo1-O3 2.304 (3) & Mo-O3(thf) 2.277 (2) & Mo-O3 2.266 (2) & Mo1-O3 2.420 (2) \\
\hline Mo1-O1 1.694 (3) & Mo-O1(oxo) 1.682 (2) & Mo1-O1 1.655 (2) & Mo1-O1 1.666 (2) \\
\hline
\end{tabular}

result of $\mathrm{H} \cdots \mathrm{H}$ interactions between interior and exterior diethyl ethers, which account for $49.9 \%$ of the surface (Fig. $3 b$ ). The points of intimate contact between the diethyl ether $\mathrm{H}$ atoms and the molybdenum-oxo bonds account for a total of $10.9 \%$ of the surface (Figs. $3 d$ and $3 e$ ). Intriguingly, contact between the meridional chloro ligands and diethyl ether $\mathrm{H}$

There are instances of intermolecular hydrogen bonding that occur between the molybdenum-oxo linkage and neigh-

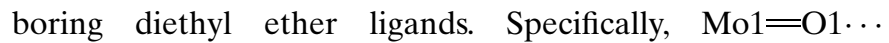
$\mathrm{H} 1 B^{\mathrm{i}}-\mathrm{C}^{\mathrm{i}}$ and $\mathrm{Mo} 1=\mathrm{O} 1 \cdots \mathrm{H} 5 B^{\mathrm{ii}}-\mathrm{C} 5^{\mathrm{ii}}$ [symmetry codes: (i) $x-\frac{1}{2},-y+\frac{1}{2},-z+1$; (ii) $\left.-x+\frac{1}{2},-y+1, z+\frac{1}{2}\right]$, with bond lengths of 2.683 and $2.572 \AA$, respectively (Fig. $1 \mathrm{~b}$ ). These two bonding interactions explain the extended Mo1=O1 bond distance [1.694 (3) ^] compared to analogous oxomolybdenum complexes (Table 3). An intramolecular close contact is also present between two meridional chloro ligands and neighboring diethyl ether $\mathrm{H}$ atoms, viz. Cl1 $\cdots \mathrm{H} 1 A-\mathrm{C} 1$, $\mathrm{Cl} 3 \cdots \mathrm{H} 4 B-\mathrm{C} 4$, and $\mathrm{Cl} 3 \cdots \mathrm{H} 8 B-\mathrm{C} 8$, with bond lengths of 2.697, 2.949, and $2.946 \AA$, respectively. Atom $\mathrm{Cl} 3$ also experiences an intermolecular contact through $\mathrm{Cl} 3 \cdots \mathrm{H} 5 A^{\mathrm{ii}}-$ $\mathrm{C}^{\mathrm{ii}}$ and $\mathrm{Cl} 3 \cdot \mathrm{H} 2 A^{\mathrm{ii}}-\mathrm{C} 2^{\mathrm{ii}}$, with bond lengths of 2.926 and $2.927 \AA$, respectively. These close contacts are a direct cause of the extended $\mathrm{Mo}-\mathrm{Cl}$ bond lengths of $\mathrm{Mo1}-\mathrm{Cl1}$ and Mo1$\mathrm{Cl} 3$ (Table 2). A basal plane was generated through the meridional plane of the complex with the equation $-0.272 x+0.709 y-0.650 z-0.536=0$ (Fig. S3 in the supporting information). The distance of the molybdenum centre from the centroid of the basal plane is $0.264 \AA$ and the fractional coordinates from the atom projection to the plane are (0.134701, 0.460936, 0.478813). This centre-centroid distance is shorter than that reported for the $\mathrm{MoCl}_{3} \mathrm{O}(\mathrm{MeOH})_{2}$ and $\mathrm{MoCl}_{3} \mathrm{O}\left[\mathrm{MeO}\left(\mathrm{CH}_{2}\right)_{2} \mathrm{OCH}_{2} \mathrm{Cl}\right]$ adducts, which display respective distances of 0.322 and $0.378 \AA$, but is similar to that of $\mathrm{MoCl}_{3} \mathrm{O}\left(\mathrm{PMe}_{3}\right)\left(\mathrm{O}=\mathrm{PMe}_{3}\right)$, which has a distance of $0.256 \AA$ (Marchetti et al., 2013; Limberg et al., 1996).

The $d_{\text {norm }}$ Hirshfeld surface $(-0.0313$ to $1.2958 \AA)$ was generated using CrystalExplorer17 (Turner et al., 2017) and can be seen in Fig. 2. There are four red portions of the surface, generated by interactions that are shorter than van der Waals radii, all of which are the result of $\mathrm{Mo}=\mathrm{O} \cdots \mathrm{H}-\mathrm{C}$ interactions between the $\mathrm{CH}_{2}$ hydrogens of the coordinated diethyl ether and the $\mathrm{Mo}=\mathrm{O}$ oxygen. Two of these interactions are the result of exterior diethyl ether hydrogens near the interior $\mathrm{Mo}=\mathrm{O}$ bond, while the other two are caused by two exterior $\mathrm{Mo}=\mathrm{O}$ bonds interacting with interior diethyl ether ligands. The Hirshfeld surface with neighboring atoms and molecules is elaborated in Fig. S4 (see supporting information). The spatial configuration of neighboring molecules is a direct result of these close contact interactions, causing the coordinated diethyl ethers to lie in proximity to one another. Because of this, the majority of the Hirshfeld surface is the atoms account for $37.4 \%$ of the Hirshfeld surface, but do not account for any of the close contact points of the surface. The remaining percentages of the Hirshfeld surface can be seen in the remainder of Fig. 3. As expected, no portions of the surface are caused by interactions, both interior and exterior, from Mo or C atoms.

\section{Conclusion}

The crystal structure and Hirshfeld surface character of mer$\mathrm{MoCl}_{3} \mathrm{O}\left(\mathrm{Et}_{2} \mathrm{O}\right)_{2}$, along with fingerprint-plot analysis, have been reported. The chloro ligands adopt a meridional configuration, with one diethyl ether ligand coordinated trans to a chloro ligand and one trans to the molybdenum-oxo bond. The molybdenum-diethyl ether bond trans to the molybdenum-oxo bond is noticeably longer than seen in analogous complexes, consistent with the lability of the coordinated diethyl ether. Intermolecular hydrogen bonds occur between the molybdenum-oxo bond and the $\mathrm{CH}_{2}$ diethyl ether groups of neighboring complexes. Unresolved is the source of the molybdenyl $\mathrm{O}$ atom in $\mathbf{2}$. All reagents were of high purity and the liquid starting materials were thoroughly dried and deoxygenated. The yield of 2 described above was estimated to be $<5 \%$. When a second reaction was carried out with identical quantities of the same reagents, but closer to room temperature, the filtrate was green and the yield of $\mathbf{2}$ increased significantly $(>10 \%)$. We surmise from this result that diethyl ether is at least a contributing source of the molybdenyl $\mathrm{O}$ atom in $\mathbf{2}$. Further work would be needed to identify the organic side products and develop a mechanistic picture of exactly how the oxygen transfer occurs. With a confirmed structure, the door is open for implementation of mer $-\mathrm{MoCl}_{3} \mathrm{O}\left(\mathrm{Et}_{2} \mathrm{O}\right)_{2}(2)$ as a potential oxomolybdenum(V) synthon.

\section{Acknowledgements}

This work was supported by start-up funding from the Department of Chemistry, College of Science, and the Faculty Cluster Initiative at the University of Central Florida.

\section{References}

Castellani, L. \& Gallazzi, M. C. (1985). Transition Met. Chem. 10, 194-195. 
Di Nicola, F. P., Lanzi, M., Marchetti, F., Pampaloni, G. \& Zacchini, S. (2015). Dalton Trans. 44, 12653-12659.

Dolomanov, O. V., Bourhis, L. J., Gildea, R. J., Howard, J. A. K. \& Puschmann, H. (2009). J. Appl. Cryst. 42, 339-341.

Kuiper, D. S., Douthwaite, R. E., Mayol, A.-R., Wolczanski, P. T., Lobkovsky, E. B., Cundari, T. R., Lam, O. P. \& Meyer, K. (2008a). Inorg. Chem. 47, 7139-7153.

Kuiper, D. S., Wolczanski, P. T., Lobkovsky, E. B. \& Cundari, T. R. (2008b). Inorg. Chem. 47, 10542-10553.

Limberg, C., Büchner, M., Heinze, K. \& Walter, O. (1996). Inorg. Chem. 36, 872-879.

Marchetti, F., Pampaloni, G. \& Zacchini, S. (2013). Dalton Trans. 42, 15226-15234.

Parsons, S., Flack, H. D. \& Wagner, T. (2013). Acta Cryst. B69, 249 259.
Persson, C. \& Andersson, C. (1993). Inorg. Chim. Acta, 203, 235238.

Rigaku Oxford Diffraction (2020). CrysAlis PRO. Rigaku Oxford Diffraction, Yarnton, Oxfordshire, England.

Sheldrick, G. M. (2015a). Acta Cryst. A71, 3-8.

Sheldrick, G. M. (2015b). Acta Cryst. C71, 3-8.

Stoffelbach, F., Saurenz, D. \& Poli, R. (2001). Eur. J. Inorg. Chem. 2001, 2699-2703.

Turner, M. J., McKinnon, J. J., Wolff, S. K., Grimwood, J. D., Spackman, P. R., Jayatilaka, D. \& Spackman, M. A. (2017). CrystalExplorer17. University of Western Australia. https://hirshfeldsurface.net.

Vitzthumecker, C., Robinson, F. \& Pfitzner, A. (2017). Monatsh. Chem. 148, 629-633.

Wardlaw, W. \& Webb, H. W. (1930). J. Chem. Soc. pp. 2100-2106. 


\section{supporting information}

Acta Cryst. (2020). C76, 947-951 [https://doi.org/10.1107/S2053229620011626]

\section{Crystal structure and Hirshfeld surface analysis of the elusive trichlorobis(di- ethyl ether)oxomolybdenum(V)}

\section{Thomas E. Shaw, Pierre LeMagueres, Alfred P. Sattelberger and Titel Jurca}

Computing details

Data collection: CrysAlis PRO (Rigaku Oxford Diffraction, 2020); cell refinement: CrysAlis PRO (Rigaku Oxford Diffraction, 2020); data reduction: CrysAlis PRO (Rigaku Oxford Diffraction, 2020); program(s) used to solve structure: SHELXT2018 (Sheldrick, 2015a); program(s) used to refine structure: SHELXL2018 (Sheldrick, 2015b); molecular graphics: OLEX2 (Dolomanov et al., 2009); software used to prepare material for publication: OLEX2 (Dolomanov et al., 2009).

Trichloridobis(diethyl ether)oxidomolybdenum(V)

Crystal data

$\left[\mathrm{MoCl}_{3} \mathrm{O}\left(\mathrm{C}_{4} \mathrm{H}_{10} \mathrm{O}\right)_{2}\right]$

$D_{\mathrm{x}}=1.700 \mathrm{Mg} \mathrm{m}^{-3}$

$M_{r}=366.53$

Orthorhombic, $P 22_{1} 2_{1} 2_{1}$

$a=8.6186(7) \AA$

$b=12.250(1) \AA$

$c=13.5681(11) \AA$

Mo $K \alpha$ radiation, $\lambda=0.71073 \AA$

$V=1432.5(2) \AA^{3}$

Cell parameters from 3727 reflections

$\theta=2.2-30.5^{\circ}$

$\mu=1.46 \mathrm{~mm}^{-1}$

$T=100 \mathrm{~K}$

$Z=4$

Block, green

$F(000)=740$

$0.6 \times 0.21 \times 0.16 \mathrm{~mm}$

\section{Data collection}

Rigaku XtaLAB Mini II diffractometer

Absorption correction: gaussian (CrysAlis PRO; Rigaku Oxford Diffraction, 2020)

$T_{\min }=0.614, T_{\max }=0.831$

7488 measured reflections

3179 independent reflections 2959 reflections with $I>2 \sigma(I)$

$R_{\text {int }}=0.042$

$\theta_{\max }=27.5^{\circ}, \theta_{\min }=2.2^{\circ}$

$h=-11 \rightarrow 10$

$k=-15 \rightarrow 15$

$l=-17 \rightarrow 16$

$$
\begin{aligned}
& w=1 /\left[\sigma^{2}\left(F_{\mathrm{o}}{ }^{2}\right)+(0.0278 P)^{2}\right] \\
& \text { where } P=\left(F_{\mathrm{o}}{ }^{2}+2 F_{\mathrm{c}}{ }^{2}\right) / 3 \\
& (\Delta / \sigma)_{\max }<0.001 \\
& \Delta \rho_{\max }=0.53 \mathrm{e} \AA^{-3} \\
& \Delta \rho_{\min }=-0.87 \mathrm{e} \AA^{-3} \\
& \text { Extinction correction: SHELXL2018 } \\
& \quad(\operatorname{Sheldrick}, 2015 \mathrm{~b}), \\
& \mathrm{Fc}^{*}=\mathrm{kFc}\left[1+0.001 \mathrm{xFc}^{2} \lambda^{3} / \sin (2 \theta)\right]^{-1 / 4}
\end{aligned}
$$

Extinction coefficient: 0.0042 (6)

Hydrogen site location: mixed

$\mathrm{H}$ atoms treated by a mixture of independent and constrained refinement 
Absolute structure: Flack $x$ determined using

1123 quotients $[(\mathrm{I}+)-(\mathrm{I}-)] /[(\mathrm{I}+)+(\mathrm{I}-)]$ (Parsons et al., 2013)

Absolute structure parameter: 0.01 (5)

\section{Special details}

Geometry. All esds (except the esd in the dihedral angle between two 1.s. planes) are estimated using the full covariance matrix. The cell esds are taken into account individually in the estimation of esds in distances, angles and torsion angles; correlations between esds in cell parameters are only used when they are defined by crystal symmetry. An approximate (isotropic) treatment of cell esds is used for estimating esds involving l.s. planes.

Fractional atomic coordinates and isotropic or equivalent isotropic displacement parameters $\left(\AA^{2}\right)$

\begin{tabular}{|c|c|c|c|c|}
\hline & $x$ & $y$ & $z$ & $U_{\text {iso }} * / U_{\text {eq }}$ \\
\hline Mo1 & $0.14299(5)$ & $0.44571(3)$ & $0.49142(3)$ & $0.01453(13)$ \\
\hline $\mathrm{Cl} 3$ & $0.28566(14)$ & $0.58992(10)$ & $0.56149(9)$ & $0.0189(3)$ \\
\hline $\mathrm{Cl1}$ & $-0.00756(16)$ & $0.33468(10)$ & $0.38785(9)$ & $0.0220(3)$ \\
\hline $\mathrm{Cl} 2$ & $-0.07724(14)$ & $0.49900(10)$ & $0.57657(9)$ & $0.0209(3)$ \\
\hline $\mathrm{O} 2$ & $0.3298(4)$ & $0.4174(3)$ & $0.3888(2)$ & $0.0174(8)$ \\
\hline $\mathrm{O} 3$ & $0.0863(4)$ & $0.5768(2)$ & $0.3751(2)$ & $0.0144(7)$ \\
\hline O1 & $0.2054(4)$ & $0.3474(3)$ & $0.5698(2)$ & $0.0168(8)$ \\
\hline $\mathrm{C} 5$ & $0.0851(6)$ & $0.5576(4)$ & $0.2693(3)$ & $0.0182(11)$ \\
\hline H5A & $0.135(6)$ & $0.491(4)$ & $0.258(4)$ & $0.022 *$ \\
\hline H5B & $0.160(6)$ & $0.612(4)$ & $0.235(4)$ & $0.022 *$ \\
\hline C6 & $-0.0733(6)$ & $0.5618(4)$ & $0.2246(4)$ & $0.0236(12)$ \\
\hline H6A & -0.066049 & 0.547134 & 0.153769 & $0.035^{*}$ \\
\hline H6B & -0.118133 & 0.634422 & 0.235048 & $0.035^{*}$ \\
\hline $\mathrm{H} 6 \mathrm{C}$ & -0.139516 & 0.506695 & 0.255753 & $0.035^{*}$ \\
\hline $\mathrm{C} 7$ & $0.0422(6)$ & $0.6881(4)$ & $0.4026(4)$ & $0.0190(12)$ \\
\hline H7A & 0.027585 & 0.691699 & 0.474858 & $0.023 *$ \\
\hline H7B & -0.058213 & 0.706262 & 0.371106 & $0.023 *$ \\
\hline C3 & $0.4417(6)$ & 0.4994 (4) & $0.3559(4)$ & $0.0224(12)$ \\
\hline $\mathrm{H} 3 \mathrm{~A}$ & 0.396033 & 0.572873 & 0.364903 & $0.027 *$ \\
\hline $\mathrm{H} 3 \mathrm{~B}$ & 0.461479 & 0.489161 & 0.284577 & $0.027^{*}$ \\
\hline $\mathrm{C} 1$ & $0.3840(7)$ & $0.3043(5)$ & $0.3786(4)$ & $0.0229(13)$ \\
\hline $\mathrm{H} 1 \mathrm{~A}$ & $0.289(6)$ & $0.265(4)$ & $0.396(4)$ & $0.027 *$ \\
\hline H1B & $0.467(6)$ & $0.293(4)$ & $0.421(4)$ & $0.027 *$ \\
\hline $\mathrm{C} 8$ & $0.1614(7)$ & $0.7714(4)$ & $0.3723(4)$ & $0.0286(13)$ \\
\hline H8A & 0.174268 & 0.769715 & 0.300548 & $0.043^{*}$ \\
\hline H8B & 0.260723 & 0.754567 & 0.404031 & $0.043^{*}$ \\
\hline $\mathrm{H} 8 \mathrm{C}$ & 0.126930 & 0.844267 & 0.392619 & $0.043^{*}$ \\
\hline $\mathrm{C} 2$ & $0.4275(8)$ & $0.2761(4)$ & $0.2751(4)$ & $0.0314(14)$ \\
\hline $\mathrm{H} 2 \mathrm{~A}$ & 0.340121 & 0.291847 & 0.231139 & $0.047^{*}$ \\
\hline $\mathrm{H} 2 \mathrm{~B}$ & 0.453518 & 0.198366 & 0.271139 & $0.047^{*}$ \\
\hline $\mathrm{H} 2 \mathrm{C}$ & 0.517573 & 0.319693 & 0.255101 & $0.047^{*}$ \\
\hline $\mathrm{C} 4$ & $0.5935(6)$ & $0.4942(5)$ & $0.4102(4)$ & $0.0346(15)$ \\
\hline $\mathrm{H} 4 \mathrm{~A}$ & 0.647842 & 0.426657 & 0.392671 & $0.052 *$ \\
\hline H4B & 0.573964 & 0.495383 & 0.481324 & $0.052^{*}$ \\
\hline $\mathrm{H} 4 \mathrm{C}$ & 0.657549 & 0.557115 & 0.391958 & $0.052 *$ \\
\hline
\end{tabular}


Atomic displacement parameters $\left(\AA^{2}\right)$

\begin{tabular}{lllllll}
\hline & $U^{11}$ & $U^{22}$ & $U^{33}$ & $U^{12}$ & $U^{13}$ & $U^{23}$ \\
\hline Mo1 & $0.01522(19)$ & $0.0139(2)$ & $0.0144(2)$ & $-0.00072(17)$ & $0.00121(18)$ & $-0.00088(18)$ \\
C13 & $0.0200(6)$ & $0.0202(6)$ & $0.0165(6)$ & $-0.0034(5)$ & $-0.0024(5)$ & $-0.0025(5)$ \\
C11 & $0.0286(7)$ & $0.0161(6)$ & $0.0213(7)$ & $-0.0050(6)$ & $-0.0044(6)$ & $-0.0019(6)$ \\
C12 & $0.0174(6)$ & $0.0251(7)$ & $0.0202(7)$ & $0.0015(6)$ & $0.0047(6)$ & $-0.0008(6)$ \\
O2 & $0.0203(18)$ & $0.0119(17)$ & $0.0200(18)$ & $0.0030(14)$ & $0.0045(15)$ & $0.0044(14)$ \\
O3 & $0.0205(17)$ & $0.0124(18)$ & $0.0103(16)$ & $0.0035(14)$ & $-0.0016(14)$ & $-0.0012(14)$ \\
O1 & $0.0164(17)$ & $0.0174(18)$ & $0.0166(18)$ & $0.0003(15)$ & $0.0010(15)$ & $-0.0014(16)$ \\
C5 & $0.025(3)$ & $0.021(3)$ & $0.009(2)$ & $0.002(3)$ & $0.002(2)$ & $-0.002(2)$ \\
C6 & $0.029(3)$ & $0.023(3)$ & $0.019(3)$ & $0.000(3)$ & $-0.007(2)$ & $-0.001(3)$ \\
C7 & $0.024(3)$ & $0.008(2)$ & $0.024(3)$ & $0.004(2)$ & $-0.001(2)$ & $-0.001(2)$ \\
C3 & $0.022(3)$ & $0.023(3)$ & $0.022(3)$ & $-0.004(2)$ & $0.007(2)$ & $0.003(2)$ \\
C1 & $0.031(3)$ & $0.018(3)$ & $0.020(3)$ & $0.012(2)$ & $0.002(3)$ & $0.002(2)$ \\
C8 & $0.041(3)$ & $0.014(3)$ & $0.031(3)$ & $-0.001(3)$ & $-0.003(3)$ & $0.000(2)$ \\
C2 & $0.051(4)$ & $0.021(3)$ & $0.022(3)$ & $0.011(3)$ & $0.007(3)$ & $-0.003(3)$ \\
C4 & $0.019(3)$ & $0.050(4)$ & $0.035(3)$ & $-0.001(3)$ & $0.005(3)$ & $-0.001(3)$ \\
& & & & & & \\
\hline
\end{tabular}

Geometric parameters $\left(\AA,{ }^{\circ}\right)$

\begin{tabular}{|c|c|c|c|}
\hline $\mathrm{Mo} 1-\mathrm{Cl1}$ & $2.3469(13)$ & $\mathrm{C} 7-\mathrm{H} 7 \mathrm{~B}$ & 0.9900 \\
\hline $\mathrm{Mo} 1-\mathrm{Cl} 3$ & $2.3530(13)$ & $\mathrm{C} 7-\mathrm{C} 8$ & $1.506(7)$ \\
\hline $\mathrm{Mo} 1-\mathrm{Cl} 2$ & $2.3159(13)$ & $\mathrm{C} 3-\mathrm{H} 3 \mathrm{~A}$ & 0.9900 \\
\hline Mo1-O1 & $1.694(3)$ & $\mathrm{C} 3-\mathrm{H} 3 \mathrm{~B}$ & 0.9900 \\
\hline $\mathrm{Mo} 1-\mathrm{O} 2$ & $2.157(3)$ & $\mathrm{C} 3-\mathrm{C} 4$ & $1.502(7)$ \\
\hline Mo1-O3 & $2.304(3)$ & $\mathrm{C} 1-\mathrm{H} 1 \mathrm{~A}$ & $0.97(5)$ \\
\hline $\mathrm{O} 2-\mathrm{C} 1$ & $1.468(6)$ & $\mathrm{C} 1-\mathrm{H} 1 \mathrm{~B}$ & $0.93(5)$ \\
\hline $\mathrm{O} 2-\mathrm{C} 3$ & $1.463(6)$ & $\mathrm{C} 1-\mathrm{C} 2$ & $1.493(7)$ \\
\hline $\mathrm{O} 3-\mathrm{C} 5$ & $1.455(5)$ & $\mathrm{C} 8-\mathrm{H} 8 \mathrm{~A}$ & 0.9800 \\
\hline $\mathrm{O} 3-\mathrm{C} 7$ & $1.463(5)$ & $\mathrm{C} 8-\mathrm{H} 8 \mathrm{~B}$ & 0.9800 \\
\hline $\mathrm{C} 5-\mathrm{H} 5 \mathrm{~A}$ & $0.93(5)$ & $\mathrm{C} 8-\mathrm{H} 8 \mathrm{C}$ & 0.9800 \\
\hline C5-H5B & $1.04(5)$ & $\mathrm{C} 2-\mathrm{H} 2 \mathrm{~A}$ & 0.9800 \\
\hline $\mathrm{C} 5-\mathrm{C} 6$ & $1.494(7)$ & $\mathrm{C} 2-\mathrm{H} 2 \mathrm{~B}$ & 0.9800 \\
\hline C6-H6A & 0.9800 & $\mathrm{C} 2-\mathrm{H} 2 \mathrm{C}$ & 0.9800 \\
\hline C6-H6B & 0.9800 & $\mathrm{C} 4-\mathrm{H} 4 \mathrm{~A}$ & 0.9800 \\
\hline $\mathrm{C} 6-\mathrm{H} 6 \mathrm{C}$ & 0.9800 & $\mathrm{C} 4-\mathrm{H} 4 \mathrm{~B}$ & 0.9800 \\
\hline $\mathrm{C} 7-\mathrm{H} 7 \mathrm{~A}$ & 0.9900 & $\mathrm{C} 4-\mathrm{H} 4 \mathrm{C}$ & 0.9800 \\
\hline $\mathrm{O} 1-\mathrm{Mo1}-\mathrm{O} 3$ & $173.06(14)$ & $\mathrm{O} 3-\mathrm{C} 7-\mathrm{C} 8$ & $112.6(4)$ \\
\hline $\mathrm{O} 2-\mathrm{Mo} 1-\mathrm{Cl} 2$ & $168.30(9)$ & $\mathrm{H} 7 \mathrm{~A}-\mathrm{C} 7-\mathrm{H} 7 \mathrm{~B}$ & 107.8 \\
\hline $\mathrm{Cl} 1-\mathrm{Mo} 1-\mathrm{Cl} 3$ & $165.00(5)$ & $\mathrm{C} 8-\mathrm{C} 7-\mathrm{H} 7 \mathrm{~A}$ & 109.1 \\
\hline $\mathrm{O} 1-\mathrm{Mo} 1-\mathrm{Cl} 2$ & $98.48(12)$ & $\mathrm{C} 8-\mathrm{C} 7-\mathrm{H} 7 \mathrm{~B}$ & 109.1 \\
\hline $\mathrm{O} 1-\mathrm{Mo} 1-\mathrm{Cl} 1$ & $98.02(11)$ & $\mathrm{O} 2-\mathrm{C} 3-\mathrm{H} 3 \mathrm{~A}$ & 108.9 \\
\hline $\mathrm{O} 1-\mathrm{Mo} 1-\mathrm{Cl} 3$ & 96.55 (11) & $\mathrm{O} 2-\mathrm{C} 3-\mathrm{H} 3 \mathrm{~B}$ & 108.9 \\
\hline $\mathrm{O} 1-\mathrm{Mo} 1-\mathrm{O} 2$ & 93.09 (14) & $\mathrm{O} 2-\mathrm{C} 3-\mathrm{C} 4$ & $113.3(4)$ \\
\hline $\mathrm{O} 3-\mathrm{Mo} 1-\mathrm{Cl} 2$ & 88.37 (9) & $\mathrm{H} 3 \mathrm{~A}-\mathrm{C} 3-\mathrm{H} 3 \mathrm{~B}$ & 107.7 \\
\hline $\mathrm{O} 3-\mathrm{Mo} 1-\mathrm{Cl} 1$ & $82.92(8)$ & $\mathrm{C} 4-\mathrm{C} 3-\mathrm{H} 3 \mathrm{~A}$ & 108.9 \\
\hline
\end{tabular}




\begin{tabular}{|c|c|c|c|}
\hline $\mathrm{O} 3-\mathrm{Mo} 1-\mathrm{Cl} 3$ & $82.19(8)$ & $\mathrm{C} 4-\mathrm{C} 3-\mathrm{H} 3 \mathrm{~B}$ & 108.9 \\
\hline $\mathrm{O} 2-\mathrm{Mo} 1-\mathrm{O} 3$ & $80.10(11)$ & $\mathrm{O} 2-\mathrm{C} 1-\mathrm{H} 1 \mathrm{~A}$ & $100(3)$ \\
\hline $\mathrm{Cl} 2-\mathrm{Mo} 1-\mathrm{Cl} 3$ & $90.87(5)$ & $\mathrm{O} 2-\mathrm{C} 1-\mathrm{H} 1 \mathrm{~B}$ & $109(3)$ \\
\hline $\mathrm{Cl} 2-\mathrm{Mo} 1-\mathrm{Cl} 1$ & $90.51(5)$ & $\mathrm{O} 2-\mathrm{C} 1-\mathrm{C} 2$ & $112.7(4)$ \\
\hline $\mathrm{O} 2-\mathrm{Mo} 1-\mathrm{Cl} 3$ & $89.52(9)$ & $\mathrm{H} 1 \mathrm{~A}-\mathrm{C} 1-\mathrm{H} 1 \mathrm{~B}$ & $115(4)$ \\
\hline $\mathrm{O} 2-\mathrm{Mo} 1-\mathrm{Cl1}$ & $86.14(10)$ & $\mathrm{C} 2-\mathrm{C} 1-\mathrm{H} 1 \mathrm{~A}$ & $109(3)$ \\
\hline $\mathrm{C} 3-\mathrm{O} 2-\mathrm{Mo} 1$ & $125.4(3)$ & $\mathrm{C} 2-\mathrm{C} 1-\mathrm{H} 1 \mathrm{~B}$ & $110(3)$ \\
\hline $\mathrm{C} 3-\mathrm{O} 2-\mathrm{C} 1$ & $114.2(4)$ & $\mathrm{C} 7-\mathrm{C} 8-\mathrm{H} 8 \mathrm{~A}$ & 109.5 \\
\hline $\mathrm{C} 1-\mathrm{O} 2-\mathrm{Mo1}$ & $116.8(3)$ & $\mathrm{C} 7-\mathrm{C} 8-\mathrm{H} 8 \mathrm{~B}$ & 109.5 \\
\hline $\mathrm{C} 5-\mathrm{O} 3-\mathrm{Mo1}$ & $124.4(3)$ & $\mathrm{C} 7-\mathrm{C} 8-\mathrm{H} 8 \mathrm{C}$ & 109.5 \\
\hline $\mathrm{C} 5-\mathrm{O} 3-\mathrm{C} 7$ & $113.6(4)$ & $\mathrm{H} 8 \mathrm{~A}-\mathrm{C} 8-\mathrm{H} 8 \mathrm{~B}$ & 109.5 \\
\hline $\mathrm{C} 7-\mathrm{O} 3-\mathrm{Mo} 1$ & $122.0(3)$ & $\mathrm{H} 8 \mathrm{~A}-\mathrm{C} 8-\mathrm{H} 8 \mathrm{C}$ & 109.5 \\
\hline $\mathrm{O} 3-\mathrm{C} 5-\mathrm{H} 5 \mathrm{~A}$ & $107(3)$ & $\mathrm{H} 8 \mathrm{~B}-\mathrm{C} 8-\mathrm{H} 8 \mathrm{C}$ & 109.5 \\
\hline $\mathrm{O} 3-\mathrm{C} 5-\mathrm{H} 5 \mathrm{~B}$ & $110(3)$ & $\mathrm{C} 1-\mathrm{C} 2-\mathrm{H} 2 \mathrm{~A}$ & 109.5 \\
\hline $\mathrm{O} 3-\mathrm{C} 5-\mathrm{C} 6$ & $113.7(4)$ & $\mathrm{C} 1-\mathrm{C} 2-\mathrm{H} 2 \mathrm{~B}$ & 109.5 \\
\hline $\mathrm{H} 5 \mathrm{~A}-\mathrm{C} 5-\mathrm{H} 5 \mathrm{~B}$ & $101(4)$ & $\mathrm{C} 1-\mathrm{C} 2-\mathrm{H} 2 \mathrm{C}$ & 109.5 \\
\hline $\mathrm{C} 6-\mathrm{C} 5-\mathrm{H} 5 \mathrm{~A}$ & $113(3)$ & $\mathrm{H} 2 \mathrm{~A}-\mathrm{C} 2-\mathrm{H} 2 \mathrm{~B}$ & 109.5 \\
\hline $\mathrm{C} 6-\mathrm{C} 5-\mathrm{H} 5 \mathrm{~B}$ & $111(3)$ & $\mathrm{H} 2 \mathrm{~A}-\mathrm{C} 2-\mathrm{H} 2 \mathrm{C}$ & 109.5 \\
\hline $\mathrm{C} 5-\mathrm{C} 6-\mathrm{H} 6 \mathrm{~A}$ & 109.5 & $\mathrm{H} 2 \mathrm{~B}-\mathrm{C} 2-\mathrm{H} 2 \mathrm{C}$ & 109.5 \\
\hline $\mathrm{C} 5-\mathrm{C} 6-\mathrm{H} 6 \mathrm{~B}$ & 109.5 & $\mathrm{C} 3-\mathrm{C} 4-\mathrm{H} 4 \mathrm{~A}$ & 109.5 \\
\hline $\mathrm{C} 5-\mathrm{C} 6-\mathrm{H} 6 \mathrm{C}$ & 109.5 & $\mathrm{C} 3-\mathrm{C} 4-\mathrm{H} 4 \mathrm{~B}$ & 109.5 \\
\hline $\mathrm{H} 6 \mathrm{~A}-\mathrm{C} 6-\mathrm{H} 6 \mathrm{~B}$ & 109.5 & $\mathrm{C} 3-\mathrm{C} 4-\mathrm{H} 4 \mathrm{C}$ & 109.5 \\
\hline $\mathrm{H} 6 \mathrm{~A}-\mathrm{C} 6-\mathrm{H} 6 \mathrm{C}$ & 109.5 & $\mathrm{H} 4 \mathrm{~A}-\mathrm{C} 4-\mathrm{H} 4 \mathrm{~B}$ & 109.5 \\
\hline $\mathrm{H} 6 \mathrm{~B}-\mathrm{C} 6-\mathrm{H} 6 \mathrm{C}$ & 109.5 & $\mathrm{H} 4 \mathrm{~A}-\mathrm{C} 4-\mathrm{H} 4 \mathrm{C}$ & 109.5 \\
\hline $\mathrm{O} 3-\mathrm{C} 7-\mathrm{H} 7 \mathrm{~A}$ & 109.1 & $\mathrm{H} 4 \mathrm{~B}-\mathrm{C} 4-\mathrm{H} 4 \mathrm{C}$ & 109.5 \\
\hline $\mathrm{O} 3-\mathrm{C} 7-\mathrm{H} 7 \mathrm{~B}$ & 109.1 & & \\
\hline $\mathrm{Mo} 1-\mathrm{O} 2-\mathrm{C} 3-\mathrm{C} 4$ & $98.5(5)$ & $\mathrm{C} 5-\mathrm{O} 3-\mathrm{C} 7-\mathrm{C} 8$ & $-68.7(5)$ \\
\hline $\mathrm{Mo} 1-\mathrm{O} 2-\mathrm{C} 1-\mathrm{C} 2$ & $143.0(4)$ & $\mathrm{C} 7-\mathrm{O} 3-\mathrm{C} 5-\mathrm{C} 6$ & $-67.0(5)$ \\
\hline $\mathrm{Mo} 1-\mathrm{O} 3-\mathrm{C} 5-\mathrm{C} 6$ & $110.8(4)$ & $\mathrm{C} 3-\mathrm{O} 2-\mathrm{C} 1-\mathrm{C} 2$ & $-57.5(6)$ \\
\hline $\mathrm{Mo} 1-\mathrm{O} 3-\mathrm{C} 7-\mathrm{C} 8$ & $113.4(4)$ & $\mathrm{C} 1-\mathrm{O} 2-\mathrm{C} 3-\mathrm{C} 4$ & $-58.9(6)$ \\
\hline
\end{tabular}

